\title{
Patriarchal Usurpation of the Modjadji Dynasty: A Gender-critical Reading of the History and Reign of the Modjadji Rain Queens
}

\author{
Kabelo O. Motasa ${ }^{1}$ \\ https://orcid.org/0000-0002-8350-8189 \\ Lilly (S.J.) Nortjé-Meyer \\ https://orcid.org/0000-0002-4625-4159 \\ Department of Religion Studies \\ University of Johannesburg, Auckland Park \\ Johannesburg, South Africa \\ E-mail: lillynm@uj.ac.za
}

Doi: https://doi.org/10.46222/pharosjot.102.1.8

\begin{abstract}
The setting of the Modjadji dynasty is on the one hand in a South African democratic space with an appraisal of women's rights, and on the other hand in a rural traditionalist setting where women have a designated place under patriarchy. How the queens navigate their rule, in circumstances where the modern and traditional seek to occupy the same space, requires a gender-critical reading. Questions about their ability to autonomously dispense their duties as queens and exercise freedom over their livelihoods in a culture that emanates from a patriarchal rule, inform the core objectives in this article. Diverging from the western form of feminism, which has been suspected of universalising challenges faced by women like Vashti and Esther, to African feminism that is more context-based, helps in unearthing patriarchal traits directly affecting African women. The intention is not to discredit one form of feminism or the other, but to explore how such a fusion can help in the emancipation of women, as this is the goal of African feminism.
\end{abstract}

Keywords: Rain queens, Modjadji, Balobedu, Balobedu Royal Council, African feminism.

\section{Opening Statement}

The Balobedu² people were ruled by the Modjadji Queens for more than 400 years. During these times, the reigning of the queens was always controversial because it was in conflict with the male-dominated Balobedu Royal Council. This conflict came to a

\footnotetext{
${ }^{1}$ Kabelo Motasa is a MA (Biblical Studies) graduate at the Department of Religion Studies, University of Johannesburg (UJ), under the supervision of Prof Lilly (S.J.) Nortjé-Meyer.

${ }^{2}$ The Balobedu or BaLobedu ba GaModjadji are a small tribe that forms part of the Sotho-Venda branch of the larger group of Northern Sotho language speakers in Limpopo Province of South Africa, Available online at https://www.tfpdfoundation.org/communities2/balobedu, retrieved 10 May 2021.
} 
climax on 9 May 2021, when the Royal Council (in a surprising move) usurped the throne and appointed Prince Lekukela Modjadji, the son of the late rain queen Makobo Modjadji VI, as king of the Balobedu people. His sister, Princess Masalanabo age 16, was 11 years old when her mother died and was destined to take over the queenship as Modjadji VII when she turns 18 in 2023. According to an announcement from the Royal Council, Princess Masalanabo will become the great-aunt (khadi-kholo), and not the queen, in the royal Balobedu family ${ }^{3}$.

The regent of the Royal Council, Mpaphatla Bakhoma Modjadji, says that the reason for the decision was the controversy around the paternity of Princess Masalanabo. It seems that the Council was under the impression that David Mohale was just a friend of Queen Makobo and not the father of Princess Masalanabo. This intimate relationship was violating the rules and authority of the Council because they have to determine who is to father the next Modjadji queen. The baby girl was taken away from the Balobedu when she was five months old. As a result, Princess Masalanabo seems to have missed several divine and sacred processes in the Balobedu culture and traditions to prepare her as heir to the throne (The Star, 19 May 2021:1). It is assumed that instead Prince Lekukela has received the divine and sacred processes to prepare him for the throne. From a gender-critical perspective, this seems to be an intentional replacement of the Modjadji queen with a King, which has been the intent of the Royal Council for many years. This is the latest move of the Royal Council to enforce patriarchal rule and ideology on the rain queen dynasty.

\section{Introduction}

'Behind every successful man, there is a woman'. ${ }^{4}$ Although this saying seems innocuous, it implies that the lives of women are lived in the shadows of men, obscured and invisible in society. This has led, consciously or unconsciously, to the societal norm that this is where women belong. The danger of this is when women themselves accept this imposed position at the expense of their lives. To avoid generalisation, this acceptance that women have chosen differs according to the socio-economic status and context in which they find themselves.

In looking at England's history, Virginia Woolf gives a glimpse of a tradition that gave men the rights not only to beat their wives but also their daughters. In that '...the daughter who refused to marry the gentleman of her parents' choice, was liable to be locked up, beaten and flung about the room, without any shock inflicted on public opinion' (Woolf, 1977:48). Such traditionally desensitized views cause violence against (and rape of) women to be taken lightly; and the irony is that such horrendous acts still happen in a democratic state like South Africa (Frenkel, 2008:1). This ideological shadow within which women find themselves has come in the forms of religion, patriarchy, colonialism, capitalism, and currently globalism (to mention only a few). The question is: Has it always been that way? Books like Digging out our foremothers by

\footnotetext{
${ }^{3}$ Available online at https://www.news24.com/news24/southafrica/news/prince-lekukela-modjadji-ascendsto-balobedu-royal-family-throne-instead-of-his-sister-masalanabo, retrieved 19 May 2021.

${ }^{4}$ When Meryll Frost received his trophy as the most courageous athlete of 1945 he said "They say behind every great man there's a woman”, available online at https://www.phrases.org.uk/meanings/behind-everygreat-man-theres-a-great-woman.html, retrieved 01 July 2021.
} 
Christina Landman (1996), and a myriad of others dedicated to unearthing and bringing women to the fore, have responded in the negative to this question. Their work gave us narratives such as those of Queen Makeda, commonly known as Queen of Sheba, and Christina Nku of the St. John's Apostolic Faith Mission. The recovery of women's history has not been easy for feminists, with many hurdles to cross (Scott, 1996:3).

The purpose of this article is to highlight the lives of formidable women, albeit with a different lens: namely a gender-critical analysis of the Queen Modjadji dynasty. Patricia Bell Scott warns, however, that most research done on women is done from a social problem approach. This approach ascribes societal ills and degenerate moral behaviour to the role that women play in black families (Scott, 1982:86). In response to the sexist, and to an extent racist, biases of the approach, she argues that:

There must be more explorations of Black father-daughter dyads and Black mother-daughter dyads, as well as other female-to-female relationships, both within and without the family group. It is only then can we speak more precisely about female socialization in the Black community (Scott, 1982:90).

This article aims at achieving three things: to apply a gender-critical approach to the history and reign of the Modjadji dynasty; to assess the Queen Modjadjis' contributions as women to the development and success of their society; to evaluate her autonomy to dispense her duties as queen and her control over her own body in terms of her choice of partner, the bearing of children, her own sexuality, and her own death.

\section{Feminist Critique of Patriarchy}

A common theme in feminist writing is the critique of patriarchy. Since that is the case, there is a greater need to understand what it is and what it means for women. De La Rey posits that "...in order to understand how "femininity" is socially constructed in such a way that women become disempowered, we must also understand how "masculinity" is constructed and inscribed in structures of power' (De La Rey, 1997:5). It is in this regard imperative to understand patriarchy as an ideology fashioned to manufacture axioms that govern social relationships and interactions between males and females. An ideology according to the definition of Deist (1987:79) is:

The ideas and manner of thinking characteristic of an individual or group, shaped by political, social, religious, and other factors (conscious, unconscious, and subconscious) and providing the frame of reference within which $\mathrm{h} / \mathrm{she}$ judge and act. An ideology is true if the ideas in it are in accordance with reality, false if they are at variance with it.

An ideology thus has a potency to shape people's consciousness about reality in that their sense of the world is continually shaped by the culture they happen to find themselves in. This jettisons the idea that individuals act autonomously. According to Idang, (2015:101-102) Decker points out that:

False consciousness represents a situation wherein subjects mistakenly believe that they act autonomously and independently from material constraints. When, in fact, the very basis of their mental activity lies in their 
relation to socially established modes of production. Divorced from an understanding of materialism, ideas reflect not reality but illusion.

This means that a study of the gender relations in a community cannot be separated from the rest of the factors that make up an individual because individuals are classed ${ }^{5}$, raced, and gendered simultaneously (De la Rey, 1997:7). Feminists sat in Accra in Ghana (2006) to forge a way forward to reconcile their ideological differences, to enable them to adequately deal with issues faced by women. It is from such a realisation of those differences that the assertion of the African feminists' position needed to be conveyed lest their attempts become futile. They thus maintained in the Charter of Feminist Principles for African Feminists (2006:4); (c.f. also Khan, 2012) that:

Choosing to name ourselves Feminists places us in a clear ideological position. By naming ourselves as Feminists we politicise the struggle for women's rights, we question the legitimacy of the structures that keep women subjugated, and we develop tools for transformatory analysis and action.

This ideological premise is an important antithesis to the ideological consciousness women existed in under patriarchy. Though feminists identified patriarchy as their chief oppressor, this ideological position had to come to terms with what Amilcar Cabral once said (1966)

We also know that on the political level our own reality - however fine and attractive the realities of others may be - can only be transformed by detailed knowledge of it by our own efforts, by our own sacrifices... however great the similarity between our various cases and however identical our enemies, national liberation and social revolution are not exportable commodities; they are, and increasingly so every day, the outcome of local and national liberation, more or less influenced by external factors (be they favourable or unfavourable) but essentially determined and formed by the historical reality of each people, carried to success by the overcoming or correct solution of the internal contradictions between various categories characterising this reality.

This was an imperative step for feminists, to realize how common and generally accepted patriarchy is. However, although there is congruency between womens' livelihoods and patriarchy, feminists needed to concede that patriarchy can never be experienced the same, as the context they are embedded in will determine how women tend to experience it. Scott notes:

Feminist history analyses the conditions which have or have not produced a shared identity of women by examining the different contexts in which women have lived, the different ways in which they have experienced their lives, the different influences of their acquiescence or resistance to the rules

\footnotetext{
${ }^{5}$ Class critique forms the gist of Marxism. The irony of this is when Marxists readily accept traditional gendered roles which were the brainchild to an extent of capitalism's top-down structure while advocating for equality on the economic front (Winslow, 2004: 196).
}

${ }^{6}$ Available online at https://www.marxists.org/subject/africa/cabral/1966/weapon-theory.htm, retrieved 26 May 2021. 
societies have elaborated for their behaviour. The results of this analysis point to fundamental differences in the identities attributed to, and avowed by women. These identities change over time, vary in different societies, and even change for the same women depending on the contexts they are in. Except for the fact of the similarity of their sexual organs, it is hard to find a common identity (Scott, 1996:5).

This creates a context-conscious approach that not only affords women the leeway to be able to convey the different shades of patriarchy they have to deal with, but in turn counters the idea of African women's struggle as being homogeneous. This ideological standpoint had to take cognizance of the past which Oyeronke Oyewumi (1999), Ife Amadiume (2001), and N. Nzegwu (2004) maintain was impacted profoundly by Christian missionaries ${ }^{7}$, colonialism, and imperialism, especially on the idea of gender in Africa (Goredema, 2010:34-35). This ideological position, though imperative, created two strands of African feminism. The problem African feminism had to contend with is who best represents the voices of marginalised women: women on the ground or those in elevated places or positions. Oyewumi's article on the conceptualization of gender in Africa argues that most of the time, scholars tend to transpose Eurocentric views of gender in Africa, without realizing that those views are unique to the West as they employ the nuclear family as a point of departure for gender analysis (Oyewumi, 1999:2). Oyewumi and others remark that gender in Africa is fluid and never rigid ${ }^{9}$. Oyewumi uses the Igbo culture in Nigeria to show that daughters of the family can be referred to as husbands to incoming wives, and that they never lose their status in their familial home even when married themselves.

These women argue that in Africa sex differentiation does not equate to sex discrimination. Amadiume bemoans how modern elite black women turn to misrepresent other women, especially those in the rural areas, and contends that the more westernized black women are the less self-assured they are, which is primarily how colonial and post-colonial education socialized them (Amadiume, 2001:51). She notes that in pre-colonial times women had shared social statuses with men, which were eroded by the introduction of colonialism, the Structural Adjustment Program (SAP), and mono economics (Amadiume, 2001:63). These two groups, intellectual feminism and popular feminism, are the ones that define African feminism because of their differing

\footnotetext{
${ }^{7}$ Ursula King, writing on the effect religion has had on the issue of gender, argues that 'the very construction of gendered identities in history is inherently linked with religious teachings, norms and values which have structured interpersonal relationships...' (King, 2004:71-72)

${ }^{8}$ Lewis, working on the shift from the apartheid era in South Africa to the post-apartheid era in relation to feminism, notes the '... displacement of the nature of gender-activism, as earlier preoccupations with women's agency and interest were jettisoned in favour of pursuing consensual rights-orientated lobbying and policy-making that postulated common rights and entitlements monitored or granted by the state'. This has meant that 'The emphasis in public discourses of gender transformation has shifted dramatically from a bottom-up... to a top-down codification that are believed to have national relevance (Lewis, 2008a:208 \& 209).

9 Bhabha argues that "An importance of colonial discourse is its dependence on the concept of "fixity" in the ideological construction of otherness. Fixity, as a sign of cultural/historical/racial difference in the discourse of colonialism, is a paradoxical mode of representation: it connotes rigidity and unchanging order as well as disorder, degeneracy and daemonic repetition' (Bhabha, 1983:18).
} 
ideologies. Moreover, there is a need for these two factions to reconcile their differences for a more united African feminism to be realized (Sachikonye, 2010).

To create a formidable ideology that can destabilize the patriarchal one which is deeply embedded in African culture, African feminism needs to challenge the discourse that constitutes personhood... (cf. Idang, 2015:100). According to the African philosophy on what constitutes a person, or what personhood is, there is the idea that '...the movement of the individual human child into full personhood, and beyond, as essentially a journey from an it to an it. The so-called ontological progression begins at birth...' (Menkiti, 2004:326; c.f. Kaphagawani, 2004:338 on the significance of the naming ceremony). It is then through gradation and other processes that a person becomes a person. If we were to accept that, it would mean that personhood permeates an individual and an individual has to fit into a culture's conception of what constitutes personhood and the name they bear (cf. Butler, 1990 on performativity). The failure to do so might get the individual removed from the tribe because they do not subscribe to the culture's ideology of personhood. This runs parallel with Simone de Beauvoir's idea of someone not born a woman but becoming one (1973:301). And it thus means that the roles that govern maleness and femaleness pre-exist and set the standards which an it has to meet. They are praised if they meet these assigned standards well and blamed if they do not. The life of an individual is a struggle to fulfil the ideal of humanness determined by cultural context. This is the cultural hurdle that African feminism has to overcome: an ideology that subconsciously suppresses the girl-child.

The prominence of the Modjadji queens invites a closer look on two counts: firstly, the fact that they are the only known female queens to rule in sub-Saharan Africa, and secondly, ipso facto, that they are in Africa where males are the ones who wield such power. It is such a point of departure that informs a gender-critical reading of their history.

\section{A Gender-critical Reading of the History and Reign of the Modjadji Dynasty}

A reflection of the history and reign of the Modjadji dynasty brings a positive and a negative gender-critique discussion: positively regarding their position as women, and negatively concerning the role of the Royal Council in their lives. This negative aspect has to do with the limits imposed by the Council in terms of the autonomy of the queens, which will be discussed later.

The story of the Modjadji dynasty started in the 1600s with a demonstration of one of the worst examples of power-play of men over women and children: Dzugundini, the daughter of a chief, fell pregnant before she was married (Krige \& Krige, 1943:5). This brought shame onto the family, and she was seen as damaged goods. The idea of shame is not only synonymous with African traditions but can be seen in Israel's history as well - it has patriarchy as a vertex.

Before delving into the shame-incurring acts of daughters, one has to look at the role of fathers vis-a-vis male heads in families. According to ancient Greek-Roman history, fathers had the power not only over the education of their children, but also had the power of life or death over them. This power was then passed on to the eldest male of the family. This meant that an unmarried daughter would fall under the rule of her 
brother when the father died (cf. Cowell, 1961:37). Cary et al (1961:142) posits in the case of a marriage that:

A married woman passed into the power of her husband... The match was arranged over her head between her father or guardian and the bridegroom (or his parent), and in consideration of a sum paid to the family to compensate for the loss of her services, she was conveyed from one household to another.

An unmarried daughter who fell pregnant would incur shame on the family and directly on the (male) house head.

Scholars agree that honour and shame are complex notions that need a thorough breaking down. This is because they form the foundation of human behaviour and how this behaviour is influenced by external factors. These external societal factors, which form an idea of what honour is, prey on the already apparent self-perceived weaknesses of the individual (Dumitrescu, 2005:15; Mahlangu, 2001:89; Hwang, 2017:668; Stiebert, 1998:1). In the ancient world, honour and shame had different connotations for males and females. Stiebert (1998:16) in this regard posits that:

Honour is hierarchical and it is honourable to submit to the greater honour of a superior; one's father, a community elder or the king, for instance. Amongst equals, however, honour is not a given but it is something which must be competed for and defended. It is a zero-sum game: one can only gain honour by depriving another man of his share. In regard to women their (honour) is arrived at through their coy, submissive and timid manner. However, once lost, a woman's honour is irrecoverable. A woman's lost honour occasions shame, which has a powerful defiling property and affects not only the woman herself but her kindred too [italics added].

We see such cases replete in the Old Testament with the fight for inheritance between Absalom and Amnon, with Amnon raping ${ }^{10}$ Tamar to shame Absalom's legitimacy to rule, and later Absalom killing Amnon (c.f. 2 Samuel 13). A similar incident happens with Lot and the angels when he offers his daughters to the gang of males (cf. Genesis 19:48). And lastly there is the horrendous display of male-male transmission of women in the story of the Levite's concubine in Judges 19. After the shaming of the husband, the story relates how the woman was not only raped to death by a gang of men, but how her body was cut up and the parts sent to the 12 tribes of Israel (Judges 19:29) (Mafana, 2013).

After Dzugundini fell pregnant, history relates how her father (the chief), as well as her brother, were suspected of fathering her child (Krige \& Krige, 1954:60). If the narrative sways toward the brother, then the motive would be to shame his father as he could not protect his women. In either case, the relation was incestuous and a shame to the family.

Incest is the ultimate display of control - 'to keep it in the family'. With this act, the girl is prevented from maturing to the next stage of womanhood, namely that of a married wife with a husband, but rather stays a prisoner of her childhood. The custom of marrying a

10 Claassens \& Gouws's (2014:471-487) comparative essay on the case of Esther and Kwezi in their fight against patriarchy gives invaluable insight into the dynamics of rape and victims raising their voices. 
sibling was not uncommon in ancient times. It is known that the Egyptian deity Isis was involved in a family relationship with her husband/brother Osiris (Ferguson 1995:14). Also, the Roman Emperors married their sisters and fathered their children, because they considered themselves as deities who could not marry a mortal human being. It is said that the Emperors were physically and mentally disabled as a result of incest, for example, Claudius, Caligula, and Nero (Du Plessis \& Lategan 1983:40-41). Although in most societies such a relationship is illegal, it is also unnaturally and genetically unacceptable (Helmenstine, 2020) ${ }^{11}$.

One has to make the contention that even though Dzugundini fled with her son from the tribe, she did not flee from the subservient nature of women under patriarchy (c.f. Melville, 2005:219). This shows how, though someone may abstract themselves from the culture they grew up in, it becomes very difficult to abstract themselves from the group consciousness that produced their identity. It is Scott (1985) who captures the essence of this when he notes 'Suppressing the knowledge produced by any oppressed group makes it easier for the group to rule because the seeming absence of dissent suggests that subordinate groups willingly collaborate in their own victimization' (Scott, 1985, cited in Collins 2009:5; cf. Beasley, 1999:12; Biko, 2005:92). And this is clear; that women can reproduce their own victimization, or in this instance their subordinate position in society.

Having a son meant that a mother would technically be under him, even though she is the one who taught him how to make rain. The reason is that, in the absence of a father and husband, the only present male (who is her son) becomes her head.

From the early beginnings of Dzugundini (c.1600) to Modjadji I (Maselekwane, c.1850), who managed to turn the Balobedu into a peaceful and prosperous tribe, the Modjadji dynasty was flooded with political instability and controversies within the royal household: father against sons; sons against father; brother against brother. Mujaji (who later became Modjadji I) conceived from Mugudo a boy-child who was strangled after birth. Later on a girl, who was named Mujaji II, was born. It might be that the boy-child was strangled because of the fear of rivalry and conspiracy among the males in the royal house, or as a fulfilment of Mugudo's prophecy that a 'frontal skirt', that is a woman, would rule the Balobedu. These family conflicts came to a head when Modjadji I was appointed as queen (c. 1800). This was the beginning of the reign of the Modjadji queens (Motasa, 2019:39-44).

The Royal Council had full control over the women of the royal house, even over the queens. The Modjadji queen was kept in seclusion; nobody was supposed to see her. She could also not make her own decisions. She was neither allowed to marry nor have children with a man of her choice, but her successor was to be fathered by someone chosen by the Royal Council. If she could not have children of her own, she should take 'wives' to bear children to ensure her future rule over her people. The wives which she took had to be from other chiefs from her village.

If the Modjadji queen had a mind of her own, insisting on marrying a man of her choice or going against tradition by living a more public life, the Royal Council would ban the

\footnotetext{
11 Helmenstine, A. M, 2020. Inbreeding: Definition and Genetic Effects. Available online at https://www.thoughtco.com/inbreeding-definition-effects-4171861 retrieved 12 Feb. 2021
} 
husband from the royal house and the village, and would not recognize the children as possible successors in the event of the Modjadji's death ${ }^{12}$.

The control that the traditional leaders of the Royal Council (only men) displayed over the rain queens, reaches its climax when the rain queens have to commit ritual suicide at the age of sixty years. In other parts of the world, a monarch reigns until he or she dies naturally. But from a gender-critical perspective the inhumane tradition of forced suicide at such a 'young' age, is considered discrimination against the aged, or that the rain queens are victims of ageism. ${ }^{13}$ It becomes apparent that any form of behaviour counter to this is looked upon with shame, like Modjadji III and Modjadji IV who became rebels. Lewis (2008a:7) notes:

\begin{abstract}
Women's independence, whether in the form of sexual autonomy or their economic independence is construed as disloyal, disobedience, a betrayal of what is 'proper' in a woman and, therefore of the nation. The codes of punishment they are subjected to, are the codes associated with the patriarchal heterosexist family: wayward women are humiliated, punished, and divested of a sense of belonging within communities.
\end{abstract}

This aching to belong to one's cultural group and the public or private humiliation of those women makes other women from the tribe fear losing their cultural identity by not acting according to the patriarchal set standards of what constitutes a proper woman (Lewis, 2008b:7; Hetegekimana, 2011:23). One need not look further than the relationship between the biblical Vashti a queen of Persia, and Esther in the Book of Esther - how Vashti was punished for standing up against patriarchy, and Esther was embraced for meeting the criteria of a perfect woman. One woman's life was the other's palimpsest (Snyman, 2021:675). The Vashti narrative permeates the lives of women who took a stand against patriarchy in one way or the other. This defiance has a footprint in the Modjadji history and how on several occasions they went against the grain of what was required from them.

\title{
Queen Modjadjis' Contributions as Women to the Development and Success of their Society
}

From a gender-critical perspective, the Queen Modjadjis' contribution as women to the success of their society can be highlighted. The first Modjadji managed to correct the chaos incurred when Magudo was king. From his youth his son, Mugodo, was treated as an outsider and a thief. And when he took over, his rule was filled with murder among his royal kinsmen, famine, wild animals terrorising the citizenry, the splitting of the tribe after his brother Khashani rose against him, the unbecoming conduct of his sons who entered the huts of his younger wives, slaughtering his cows randomly and disregarding him in any way possible (Krige \& Krige, 1943:8). These seem like scenes from King David's rule, when his sons fought against each other and later Absalom tried to usurp his throne, raping his concubines (cf. 2 Samuel 16:21-22; 20:3). It is after much confusion within the tribe that Modjadji I managed to turn the tribe into one that was peaceful and

\footnotetext{
12 Available online at http://rainqueensofafrica.com/2011/03/the-rain-queen-and-the-lobedu-a-north-sothotribe/, retrieved 20 May 2020

${ }^{13}$ The practice to discriminating against people on the basis of their age (Keane, 1998:121).
} 
prosperous. Through her reign, she was able to attract many outsiders, who came to see this great figure who was said to be immortal.

She was approached by neighbouring kings and chiefs for advice, and asked for her mediation for rain. On a more social level, the Modjadji queens continued to achieve the type of communalism that Nkrumah and his contemporaries dreamt of implementing. Bell (2002:39) (cf. also Masolo (2004:483-498) defines the nature of African humanism as follows:

African humanism... is rooted in traditional values of mutual respect for one's fellow kinsman and a sense of position and place in the larger order of things: one's social order, natural order and the cosmic order. African humanism is rooted in lived dependencies.

In the Balobedu culture, competition and precociousness are looked down upon and mutuality is praised (Krige et al, 1954: 76). Examples of this include the lejeme collective social event and the stokvel. The lejeme is an event in which, when there is heavy work to be done, an event is organised and beer is brewed for the people who will be working. The beer itself is not seen as a catalyst for the work or even as a form of payment. Rather the idea is to forge social interaction and cooperation amongst fellow kinsmen. The activity itself is not time-bound, and is thus not hurried through. Another example of cooperation is when neighbours help each other to hoe their farms in no particular order. Lastly, the stokvel, is when a group of people helps each other financially by agreeing on an amount of money that each member is to contribute. The money is collected and the system is rotational, with each member getting a share (Krige et al, 1943: 52-56).

The other significant factor in the Modjadji dynasty is the role that women generally play in society. Tucker (2004:397) notes on studies done of elite women that only royal elite women had a more private life than public, and that their common working-class or rural women enjoyed what their counterparts lacked. This is evident in the Modjadji dynasty. For example, an elder sister in the family is considered as a ritual head in her brother's household and a priestess who needs to ensure the wellbeing of her brother's children. The sister amasses a lot of power in her brother's house because her bride-price might have been used to secure his marriage, and she can even dissolve that marriage (Krige \& Krige, 1943:79). Beyond that, the role that women have in the homestead transcends into the society through their participation in the rain rituals. Women go to the queen to solicit rain for their families. Women play a fundamental role in the rain ritual: e.g. the snake dance, which young girls do during the ceremony. The snake is symbolic of goddess cultures in that it represents renewal (Baring \& Cashford, 1993:321).

\section{The Autonomy of the Queen}

The culture from which Dzugundini broke away, and the culture that Modjadji I reigned over, was patriarchally structured. This can be seen from the type of marriage system employed: polygyny cements the man's position as head, with females subservient to him. The male figures in the Modjadji narrative stand as shadows over the queens' rule. From a shunned people, Modjadjis were used as the means to fulfil a prophecy, then to be queens whom the Royal Council avidly tries to keep in seclusion to fulfil a mysterious formula, starting with Modjadji I (Achebe, 2020: 72). One may ask: Does a public life affect the potency of the rain medicine, or does it make the queens incapable of 
transforming the clouds? The answer is within their history. Firstly, their ancestor king, Mohale and his predecessors, fought with other tribes for the establishment of the kingdom. This would surely mark a very public life for the men. Secondly, it is to question whether the kings' bodies were as restricted from public appearances as the queens' were, then surely the secluded lifestyle and mystery that surrounded the queens would have been as thoroughly documented by scholars concerning the lives of the kings as it is done concerning the queens. The fame of the queens would have fallen into the cultural continuum as a sort of modus operandi, and nothing out of the ordinary would have been noted. Visitors to the Balobedu were intrigued by stories of a queen who is said to be immortal and who lives in seclusion (Krige \& Krige, 1943:10).

Moreover, from the Modjadji narrative one notes that the rain horn, beads and medicine are kept in secret, and only the queen knows about them. This correlates with the practice of the Tswana people (cf. Shapera, 1971); Kgabyana of the Tswana people faced fierce contention from both her brother and society in general when she tried to take over after her father. Kgabyana's detractors succeeded in preventing her ascension because they did not want to be ruled by a woman. A woman's rule is viewed with scorn and doubt, as shown in both Kgabyana's and the queen Modjadji's rule. More recently, Baleka Mbete bemoaned the psyche of the people when asked what will happen if South Africa would have a female president, saying that '...South Africa is not psychologically ready because women are thought of as not the type of people to lead' (Maphanga, 2019).

Another factor that advances the idea that the queens' rule is overshadowed by the kings' past, is that the Lobedu are in totality known as Balobedu ba Mohale. Mohale is the Balobedu people's ancestor-king who was able to form a coherent community after the defeat of the inhabitants of the Daja caves. How is the queens' rule overshadowed then? To answer adequately is to look at the social structure that permeates the Balobedu people. Polygyny ${ }^{14}$ is the important cog that shapes the entire social make-up of the Balobedu. Each wife has her own house and fields, and intimate relations with the husband are kept to a minimum. This is because of the clear segregation of the sexes. Although the wife is 'free to do anything', she cannot go to her mother's side of the family and cannot have dealings with strangers, or even give them a tour of the village. Though the husband is absent from the house, his presence is by virtue of his marriage to the wife and as her 'head'. This is like a soldier who is married but goes to war elsewhere. However, when in old age, the husband can stay with his favourite wife. Why this is important is because when Mogodo wanted to fulfil his prophecy that the tribe should be led by a woman, he was presumably in his old age. He first went to his favourite daughter (which one supposes to be from the favourite wife) to entice her to play a part in advancing his means, but she defied him. He then went to his other wife from a nearby village, which the people characterized as having sloths and a despised locale. This very village would be the place where the Modjadji queendom would take root. This is the place that marked the future leadership and chieftaincy of the Balobedu people. Modjadji I, having conceded to her father's vision, not only inherited the chieftaincy of her father but also his wives. This made her the chief patron of the tribe and a husband to all the wives. This is the same with married women in general within the tribe, for although they can live their lives the way they want, that freedom is overshadowed by their husbands.

\footnotetext{
14 Polygyny is the state of having more than one wife or female mate at a time. Available online at https://www.merriam-wester.com/dictionary/polygyny, retrieved 20 Jun 2020.
} 
That being said, things get a bit complex because of the dual roles the Modjadji ought to play, as a woman and as the new chief. As a woman, she cannot officiate over men's affairs or be in their company (except for those of her homestead). Women, as adumbrated, should tend to women's issues and not those of men because of the segregation. The paradox of this is that she has to rule over the same men who she is barred from addressing as their leader. This is why one hypothesis is that Modjadji I and the queens who succeeded her presided over a patriarchal social structure, set up with a man as head and women as subordinates. And when the queens take office, they dare not tamper with that clause, set up and regulated by the Royal Council, by acting otherwise. Since the queen cannot participate with other women in cultivating her fields, she is further pushed into her house - a huckster in a hut. In a study conducted on the Balobedu's neighbours, the Venda people, Matshidze (2013: 68) posits thus regarding African leadership:

It is noteworthy that the power of the office is vested in the position, and not necessarily the person who occupies it. This means that the traditional leader does not have power in his personal capacity, but he derives power from his position as traditional leader.

For women in traditional leadership roles, being female further stratifies them into exclusion from decision-making positions.

The above views arise because of the 'patriarchal regulation of bodies in its society' (Nortjé-Meyer, 2005a:732), which encrypts into a society that certain roles belong to the female and other roles belong to the male, thereby advocating that women cannot be in leadership roles and that they should only behave in a certain prescribed way. This is why the contribution to the governing of the kingdom of Israel of certain biblical women has been downplayed and in some cases 'their queenships were not recognized i.e. Bathsheba, Jezebel, and Athaliah, solely because they were viewed as women and foreigners' (Nortjé-Meyer, 2005b:29-36).

There were Modjadjis who stood up against patriarchal domination by rejecting the tribal traditions. Lewis (2008a:3) notes the demands and hurdles of feminist leadership in that it:

... would mean deliberative and servant leadership, democratic leadership
that involves people in true dialogue. Feminist leadership would therefore
mean a radical challenge to the state as a site of authoritarian control and
elite consolidation... [F]or women to make a true difference as political
leaders they would need to take a stand against class and power injustices
at the same time that they confront the patriarchy of the state.

This is evident in the Modjadjis who followed their own ways by marrying their own husbands and having children with them. They refused to commit the ritual suicide at the age of sixty and reigned until they died naturally, like Makoma Modjadji IV. Modjadji VI was the first modern rain queen to receive a formal education. She challenged the traditions by not living a secluded life. She was known for attending discos, wearing jeans, watching soap operas, and chatting on social networks ${ }^{15}$. The future queen,

\footnotetext{
${ }^{15}$ Available online at http://rainqueensofafrica.com/2011/03/the-rain-queen-and-the-lobedu-a-north-sothotribe/, retrieved 20 Jun 2019.
} 
Princess Masalanabo, is currently receiving education and aspires to be a medical doctor. This raises the question of whether, once becoming queen, the cultural rules are going to restrict her to her house or allow her to celebrate her aspirations? The Royal Council saw Modjadji VI as someone who did not embody the characteristics of a traditional queen because of her actions. They did not recognise her children with David Mogale, saying that they do not have the royal blood in them. She stayed with her partner at the royal house and established a new council which did not sit well with the old council. Her partner was later expelled from the village ${ }^{16}$.

Some scholars have regarded the Modjadjis as lesbians, because of the 'wives' they took as their 'husband'. The children they conceived were said to belong to her even if they were fathered by another man. There are two things to bear in mind in this regard: their political and social context. Politically the queen is said to reign over a hundred and fifty villages, and realistically she cannot be present in all those villages (just like the president of any country cannot be in every part of the country). She needs representatives. Through these 'wives', relationships are forged in the manner of maintaining support for her. In her case those relationships happen in the manner of marrying each village chief's daughter (Krige \& Krige, 1980:245). Socially, one should go back to the palaeolithic and neolithic times, in which goddesses reigned and where no male could claim a child as his own (Ferguson, 1995:8-11). This critique on females is also evident in the interpretation of Emma by Jane Austen, where she is considered by many scholars as being male (cf. Duckworth, 2002:67 and also Trilling, 1967:144). The other can be sister, brother, aunt, and uncle. This is very different in most African countries, where the sister of a brother becomes the husband of the brother's wife (cf. Mohale, 2014; Oyewumi, 1999). Mohale (2014) further extends this type of cross-cousin marriage system in that they create a bond between mothers and sons and fathers and daughters as it is matrilateral in nature (Mohale, 2014:27). In Lobedu culture, it is a norm that every girl is born to marry into her father's sister's family. This system demands a brief explanation as to how the Queen then becomes categorised as male.

In an interview that Mohale (2014) conducted with Moyana and Setlhabane in 2012, it is said that same-sex marriages are common in the Balobedu culture. The interviewees said that when a woman in the royal family is barren, a close relative is given to the king to impregnate her to procure an heir to the throne. The barren woman will be regarded as the father of that child. In other instances, a woman is also allowed to marry a daughter-in-law, who is then allowed to find a lover to impregnate her. The child from such an arrangement is regarded as the mother-in-law's, and the mother-in-law is regarded as responsible for both the child and mother as a husband (Mohale, 2014:26 \& 27). This is how Queen Masalanabo Modjadji II, though barren, took a wife to bear children for her.

There is a sect within the Modjadji royal house that wants the return of the patriarchal form of rule rather than the matriarchal one (Krige \& Krige, 1980:246). The Makoto part of the Royal Council still holds that the Modjadjis stole the throne from them, and their dissatisfaction was further escalated when President Ramaphosa announced the successor to the throne. The Modjadjis' rule is of the same pattern as Harriet Tubman ${ }^{17}$

\footnotetext{
${ }^{16}$ Available online at https://www.tfpdfoundation.org.balobedu, retrieved 23 Jun 2019.

${ }^{17}$ Harriet Tubman had helped many black people escape from slave-owners in the US southern states through the famous Underground Railroad started by abolitionists (cf. Michals, 2015).
} 
from the USA who freed her people from slavery. The queens, however, freed their people from the vices of drought by giving them the lifeline: water, rain. Water means life! The queens' rule is something Kgabyana of the Tswana people would have inspired if she had been inaugurated as their ruler. When taking the Modjadjis as an archetype, one is inclined to realize that the queendom of Modjadjis superseded that of their forefathers and saw scores of people coming to the Balobedu tribe, even renowned kings such as Shaka Zulu and Moshoeshoe from Lesotho. Their leadership style nullifies the stereotype that sees 'males as managers, initiators, and doers and females as mere receivers' (Nortjé-Meyer, 2005a:737). Leadership does not have a gender but a character. To some extent King Mohale's rule overshadowed that of the queen from the beginning. But socially her rule has granted the women in society power, directly and indirectly: directly through the central role they play during the rain-making rituals, and indirectly through the community work that women do in uplifting each other. Women, generally, are known to draw inspiration from each other through especially adverse times. And the strength and bravery they summon from their fellows gives testament in the following proverbs mustered up from their traits: Wathinta umfazi wathinta imbokodo (you strike a woman you strike a rock) and mosadi otshwara thipa kabohaleng (a woman holds a knife at its sharpest side).

\section{Conclusion}

In conclusion, gender roles, as the brainchild of patriarchy, displace women from active roles of power and leadership, especially in traditional settings. Patriarchy creates gender definitions that symmetrically confine women in certain spaces and bar them from those that are thought of as belonging to their male counterparts. This means that even if women were to assume higher social positions, they could not escape the ideological matrix that patriarchy creates (of them being subservient to males). This is evidenced in the covert role that the Royal Council has played in the history of the Modjadji queens, by subjecting them to criteria that do not allow them to marry their partners (but only to take wives as a king would), prevents them from addressing crowds of men, and requires unnatural death. This was met with rebellion by certain queens who lived their lives as they saw fit, an act that was looked down upon and deemed taboo by the Royal Council.

The Royal Council's deep-seated disdain for being led by a queen finally broke out into the open when they shunned Princess Masalanabo, relegating her to the position of khadzi-khulu (great-aunt) and opting for her brother to take over ${ }^{18}$. Their choice of leader (a male king) overtly undermines the historical advances that the queens have made, which included amongst other things resolving the internal conflict that plagued the tribe and catapulting the tribe to the fore with their rain-making abilities. This act puts the queenship of the Modjadji legacy in the darker shades of patriarchy's shadow. Scores of women, in all spheres of life, have tried to show that leadership is not consecrated to the male gender, but is in itself a gender-neutral attribute that accommodates any individual who has the capacity to embody it.

\footnotetext{
${ }^{18}$ Available online at https://www.news24.com/southafrica/news/prince-lekukela-modjadji-ascends-tobalobedu-royal-family-throne-instead-of-his-sister-masalanabo-20210509, retrieved 09 May 2021.
} 
The Royal Council's belligerence shows in the microcosm that women's liberation and proper recognition (not just on paper) is still a struggle that sadly still continues in South Africa.

\section{References}

Achebe, N. (2020). Female Monarchs and Merchant Queens in Africa, Ohio University Press: Ohio.

Amadiume, I. (2001). 'African Women: Voicing Feminism and Democratize Futures', International Feminisms: Divergent Perspectives, 10, [Available online at https://core.ac.uk], retrieved 16 Jul 2019.

Baring, A. \& Cashford, J. (eds.) 1993. The Myth of the Goddess: Evolution of an Image, Penguin Book: London.

Beasley, C. (1999). What is Feminism? An Introduction to Feminist Theory, Sage: Michigan.

Bell, R.H. (2002). Understanding African Philosophy: A cross-cultural approach to classical and contemporary issues, Routledge: London.

Bhabha, H. (1983). 'The Other Question', Screen, 24(6), 18-36 [Available online at https://doi.org/10.1093/screen/], retrieved 24 Jun 2018.

Biko, S. (2005). I Write What I Like, ProQuest LLC: Cambridge.

Butler, J. (1990). Gender Trouble, Routledge: New York.

Cabral, A. (1966). The Weapon of Theory. Address delivered to the first Tricontinental Conference of the Peoples of Asia, Africa and Latin America held in Havana in January, 1966. [Available online at https://www.marxists.org/subject/africa/cabral/1966/weapontheory.htm], retrieved 26 May 2021.

Charter of Feminist Principles for African Feminists http/ Available online at www.africanfeministforum.com/the charter -of-feminist-principles-for African feminists/, retrieved 26 May 2021.

Cary, M. \& Haarhoff, T.J. (1961). Life and Thought in the Greek and Roman World, Methuen \& Co: London.

Claassens, J. \& Gouws, A. (2014). 'From Esther to Kwezi: Sexual Violence in South Africa Twenty Years after Democracy', International Journal of Public Theology, 8(4), 471-487.

Collins, P.H. (2009). Black Feminist Thought: Knowledge, Consciousness, and the Politics of Empowerment, Routledge: New York.

Cowell, F.R. (1961). Everyday Life in Ancient Rome, Bradford: London. 
Deist, F. \& Le Roux, J.H. (eds.) (1987). Revolution and Reinterpretation: Chapters from the history of Israel, Literatuur van die Ou Testament 4, Tafelberg: Cape Town, 101-159.

De Beauvoir, S. (1973). The Second Sex, Vintage Books: New York.

De La Rey, C. (1997). South African Feminism, Race and Racism, Agenda: Empowering Women for Gender Equity, 13(32), [Available online at https://doi.org/10.1080/10130950.1997.9675578].

Duckworth, A.M. (ed.) (2002). Jane Austen, Emma: Complete, Authoritative Text with Biographical, Historical and Cultural Context, Critical History and Essay from Contemporary Critical Perspectives, Boston Press: Boston.

Dumitrescu, C. (2005). Shame and Honor: Biblical Understandings and Islamic Cultural Reflections, Journal of Adventist Mission Studies, 1(4), 14-39. Andrews University: Digital Commons [Available online at https://digitalcommons.andrews.edu/jams/vol1/iss1/4], retrieved 05 Jan 2020.

Du Plessis, P.J. \& Lategan, B.C. (1983). Agtergrond en Geskiedenis van die Nuwe Testament. Academia: Pretoria.

Ferguson, M. (1995). Women and Religion. Prentice Hall: New Jersey.

Frenkel, R. (2008). Feminism and Contemporary Culture in South Africa, Africa Studies, 67(1), 1-10, [Available online at https://www.tandfonline.com/doi/full/10.1080/00020180801943065?scroll=top\&needAcc ess=true], retrieved 16 Feb 2019.

Frost, M. 1945. They say behind every great man there's a woman, [Available online at https://www.phrases.org.uk/meanings/behind-every-great-man-theres-a-greatwoman.html], retrieved 30 June 2021.

Goredema, R. (2010). African Feminist: the African Woman's Struggle for Identity, African Yearbook of Rhetoric, 1(1), 33-41, [Available online at https://hdl.handle.net/10520/EJC169591], retrieved 04 Jan 2020.

Helmenstine, A.M. (2020). Inbreeding: Definition and Genetic Effects, [Available online at https://www.thoughtco.com/inbreeding-definition-effects-4171861], retrieved 12 Feb. 2021

Hetegekimana, C. (2011). Women's Empowerment in the Post-1994 Rwanda. A Case Study of Mayaga Region. Nelson Mandela Metropolitan University: Port Elizabeth.

Hwang, J. (2017). How long will my Glory be Reproach? Honour and Shame in Old Testament Lament Traditions, Old Testament Essays, 30(3), 684-706, [Available online at https://doi.org/10.17159/2312-3621/2017/v30n3a9] .

Idang, G.E. (2015). African Culture and Values, Phronimon, 16(2), Available online at https://hdl.handle.net/10520/EJC189182, retrieved 5 May 2021. 
Kaphagawani, D.N. (2004). 'African Conception of a Person: A Critical Survey', in K. Wiredu (ed.), A Companion to African Philosophy, Blackwell Publishing: Oxford, 332342.

Keane, M. (1998). Feminist and Womanist Theology, in S. Maimela \& A. Konig (eds.), Initiation into Theology. The Rich Variety of Theology and Hermeneutics, Van Schaik: Pretoria, 121-135.

Khan, S. (2012). Feminism: Manifestation of Power in Colonial Context, International Conference on Society, Humanity and History, 44, 133-137.

King, U. (2004). Religion and Gender: Embedded Patterns, Interwoven Frameworks, in T.A. Meade \& M.E. Wisner-Hanks (eds.), A Companion to Gender History, Blackwell Publishing: Oxford, 70-85.

Krige, E.J. \& Krige, J.D. (1943). The Realm of a Rain-queen: A Study of the Pattern of Lovedu Society. Published by O.U.P. for I.I.A.L.C.

Krige, E. J \& Krige, J.D. (1954). The Lovedu of the Transvaal, in D. Forde (ed), African Worlds: Studies in the Cosmological ideas and Social values of African Peoples, Oxford University Press, Great Britain

Krige, J.D. \& Krige, E.J. (1980). The Realm of a Rain Queen. Juta: Johannesburg.

Landman, C. (1996). Digging up our Foremothers: Stories of Women in Africa, Unisa Press: Pretoria.

Lewis, D. (2008a). Discursive Challenges for African Feminism [Available online at https://www.researchgate.net/publication/237455457]

Lewis, D. (2008b). South Africa, African Feminism and Challenges of Solidarity, in G. Ruiters (ed.), Gender Activism: Perspectives on the South African Transition, Institutional Cultures and Everyday Life, Rhodes University, Institute of Social and Economic Research, Grahamstown.

Mafana, C. (2013). Judges 19: The Story of The Unnamed Woman. Available online at [https://sites.stewards.edu/pangaea/judges-19-the-story-of-the-unnamed-woman/, retrieved 22 Jan 2020].

Mahlangu, E. (2001). The Ancient Mediterranean Values of Honour and Shame as a Hermeneutical Procedure: A Social-scientific Criticism in an African Perspective, Verbum et Ecclesia, 22(1), 85-101.[ Available online at https://doi.org/10.4102/ve.v22i1.625]

Maphanga, C. (2019). South Africa 'not psychologically ready for a female president' Baleka Mbete. [Available online at https://m.news24.com/SouthAfrica-notpsychologically-ready-for-a-female-president-baleka-mbete-20190805, retrieved 21 Nov 2019].

Masolo, D.A. (2004). Western and African Communitarianism: A comparison, in $\mathrm{K}$. Wiredu (ed.), A Companion to African Philosophy, Blackwell Publishing: Oxford, 483498. 
Matshidze, P.E. (2013). The Role of Makhadzi in Traditional Leadership Among the Venda, KwaZulu Natal, University of Zululand.

Menkiti, I. A. (2004). On the Normative Conception of a Person, in K. Wiredu (ed.), A Companion to African Philosophy, Blackwell Publishing: Oxford, 324-331.

Melville, S.C. (2005). Royal Women and the Exercise of Power in the Ancient Near East, in Shell, D (ed.), A Companion to the Ancient Near East, Blackwell Publishing: Oxford, 219-228.

Michals, D. (2015). Harriet Tubman. [Available online at https://www.womenshistory.org/education-resources/biographies/harriet-tubman], retrieved 27 April 2020.

Mohale, R.M. (2014). Khelobedu Cultural Evolution Through Oral Tradition, [online available at uir.unisa.ac.za], retrieved on 27 April 2020.

Motasa, K.O. (2019). Women as Queens on the Periphery of their own Reign: Reading the Rain Queen Modjadji-Tradition Gender-Critically, MA Dissertation, University of Johannesburg, Johannesburg.

Nortjé-Meyer, L. (2005a). Questioning the "Perfect Male Body": A Critical Reading of Ephesians 4:13, Scriptura, 90, 701-739.

Nortje-Meyer, L. (2005b). 'Queenship in Israel', in J.A. Du Rand (ed.), J.H. Coetzee, S.J. Nortje-Meyer \& H. Viviers, Coming to Grips with the World and Text of the Bible, Department of Biblical and Religious Studies, University of Johannesburg, Johannesburg, 29-36.

Nzegwu, N. (2004). 'Feminism and Africa: Impact and limits of the metaphysics of Gender', in K. Wiredu (ed.), A Companion to African Philosophy, Blackwell Publishing: Oxford.

Oyewumi, O. (1999). 'Conceptualizing Gender: The Eurocentric Foundations of Feminist Concepts and the Challenge of African Epistemologies', in N. Nzegwu, \& M. Dilliard (eds.), A Journal of Culture and African Women Studies, Available online at www.africaknowledgeproject.org, retrieved 13 Apr 2019.

Sachikonye, T. (2010). African Feminism Driven by African Women, [Available online at www.ngopulse.org], retrieved 13 Apr 2019.

Schapera, I. (1971). Rainmaking Rites of Tswana Tribes: African Social Research Documents, African Studies Centre, Cambridge.

Scott, P.B. (1982). Debunking Sapphire: Toward a Non-Racist and Non-Sexist Social Science, in G.T. Hull, P.B. Scott \& B. Smith (eds.). All the Women Are White, All the Blacks Are Men, But Some of Us Are Brave: Black Women's Studies, The Feminist Press: Old Westbury, NY, 85-92. 
Scott, J.C. (1985). Weapons of the Weak: Everyday Forms of Resistance, Yale University Press: New Haven / London.

Scott, J.W. (1996). Feminism and History, Oxford University Press: New York.

Snyman, G. (2012). The African and Western Hermeneutics Debate: Mimesis, The Book of Esther, and Textuality, Old Testament Essays, 25(3), 657-684.

Stiebert, J. (1998). The Construction of Shame in the Hebrew Bible: The Prophetic Contribution, PhD thesis, University of Glasgow [Available online at https://eleanor.lib.gla.ac.uk/record=b1731697], retrieved 28 Feb 2020.

The Citizen. (2018). Ramaphosa Ignites Royal Family feud over Rain Queen. [Available online at https://citizen.co.za/news/south-africa/1890921/ramaphosa-ignites-royal-familyfeud-over-rain-queen/],_retrieved 19 Jan 2020.

The Star. (2021). Modjadji Throne Spat Heads to Court. Ascension of Prince to Rule over Balobedu 'deviates from custom', Wednesday 19 May 2021, Johannesburg.

Trilling, L. (1967). Beyond Culture: Essay on Literature and Learning, Peregrine: London.

Tucker, J. (2004). Rescued from Obscurity: Contributions and Challenges in Writing the History of Gender in the Middle East and North Africa, in T.A. Meade \& M.E. WiesnerHanks (eds.), A Companion to Gender History, Blackwell Publishing: Oxford, 293-412.

Winslow, B. (2004). "Feminist Movements: Gender and Equality', in T.A. Meade \& M.E. Wiesner-Hanks (eds.), A Companion to Gender History, Blackwell Publishing: Oxford, 186-210.

Woolf, V. (1977). A Room of One's Own, Grafton: London. 